\title{
Genetic parameters of aggressiveness, ferocity and mobility in the fighting bull breed
}

\author{
Beatriz SILVA $^{\mathrm{a}}$, Ana GONZALO ${ }^{\mathrm{b}}$, Javier CAÑóN $^{\mathrm{a} *}$ \\ a Laboratorio de Genética Animal, Facultad de Veterinaria, 28040 Madrid, Spain \\ b Ganaderías Domecq Solís, Velázquez, 53, 28001 Madrid, Spain
}

(Received 19 April 2005; accepted 12 September 2005)

\begin{abstract}
Genetic parameter estimates for Aggressiveness, Ferocity and Mobility in the fighting bull bovine breed were obtained using the restricted maximum likelihood (REML) methodology applied to a multiple trait animal model. The year of birth and the sex of the animal were the environmental fixed effects considered in the model. Genetic trends were determined from the average predicted breeding value over the year of birth. The behavioural traits considered showed an important additive genetic component which can be used to modulate the phenotype expression by selection. Heritability values around $0.3(0.286-0.362)$ for all traits could explain the successful empirical selection carried out on the Aggressiveness trait. Similarly, the lack of genetic correlation $(P>0.05)$ between all traits explains the absence of a correlated response for the Ferocity and Mobility traits.
\end{abstract}

cattle / behaviour traits / fighting ability / genetic parameters

Résumé - Paramètres génétiques pour les caractères Agressivité, Férocité et Mobilité chez le taureau de combat. Les estimations des paramètres génétiques pour les caractères Agressivité, Férocité et Mobilité chez le taureau de combat ont été obtenues en utilisant la méthode du maximum de vraisemblance restreint (REML) appliquée à un modèle animal multi caractères. L'année de naissance et le sexe ont été retenus comme effets fixes. Les tendances génétiques ont été déterminées à partir de la valeur additive moyenne au cours de l'année de naissance. Les caractères de comportement considérés montrent des composantes génétiques additives importantes qui peuvent être utilisées pour moduler l'expression phénotypique par sélection. Les valeurs d'héritabilité pour tous les caractères sont d'environ $0,3(0,286-0,362)$ ce qui peut expliquer l'efficacité de la sélection empirique sur le caractère Agressivité. De la même manière, le manque de corrélation génétique $(P>$ $0,05)$ entre tous les caractères explique l'absence d'une réponse corrélée pour les caractères Férocité et Mobilité.

bovin / caractères de comportement / aptitude au combat / paramètres génétiques

\footnotetext{
* Corresponding author: jcanon@vet.ucm.es
} 


\section{INTRODUCTION}

Aggressiveness and Ferocity are important behavioural traits in domestic animal species. Important variability between populations, e.g. breeds, within species is commonly accepted and the recognition of a genetic background for these traits is implicit $[13,15]$. More recently, it has become increasingly accepted that genetic variation makes an important contribution to individual, and population differences [12] and is within the normal range of behaviour that includes general ability traits [11]. Knowledge of the relative importance of the genetic component for the behaviour traits related to Aggressiveness would allow for the development of strategies to genetically modulate its expression within a breeding population.

Although this objective may be important above all for animal species, there have been few studies dealing with genetic parameters of cattle behavioural traits. Some exceptions are the estimates of the heritability for dominance [17], docility [8] or temperament [1]. Estimation of genetic parameters such as heritabilities and genetic correlation requires objective phenotypic and pedigree information among recorded animals. Relationships among animals in a population with phenotypic and pedigree information is essential to the accuracy of the genetic analysis. While morphological and (many) productive traits can be measured easily and accurately, behavioural traits are more complex and most often determined in a subjective manner which can lead to errors in the process of assigning animals to classes or categories. These resulting errors increase the residuals thereby reducing heritability estimates.

Fighting bull cattle is one of the most important Iberian breed distributed in many countries all over the world, from Europe (France, Spain, Portugal) to many of the North, Central and South American countries. The breed has been empirically selected for their behavioural traits, especially those related to Aggressiveness, during the past five centuries and are famous for their ten- dency to fight someone provoking them with some kind of lure. Distinct breeding lines, many of them genetically closed, make it difficult to find genetic relationships among animals across lines even though phenotypic information exists within lines. Fortunately, the size of the herd of the most important and genetically influential subpopulations may be sufficient to estimate genetic parameters within an acceptable error level.

Traditional practices of a fighting bull production system include registration of the correct pedigree information and recording of each animal's scores on an important set of behavioural traits that include Aggressiveness, Ferocity, and Mobility.

The objective of this paper was to analyse the main genetic parameters for Aggressiveness, Ferocity, and Mobility in order to consider the possibilities the genetic selection offers to reduce the frequency of the undesirable categories for behavioural traits related with aggressiveness.

\section{METHODS}

\subsection{Performance recording system}

Males were scored at three to four years of age during an actual bullfight held in a fighting bull arena called a plaza (bullring), whereas cows were scored at two years of age in a field at the ranch called a tienta, which simulates the plaza environment and conditions. It should be noted that the animals were scored only once since they are capable of remembering what is involved in the test thus making subsequent bullfights dangerous and that two data collectors perform the phenotypes, one until the year of 1978, and since 1979 for the other one.

Traits recorded and ad hoc definitions were the following:

- Aggressiveness (Agg) - Fighting ability; wildness. The more the animal faces the bullfighter rather than trying to escape, the higher the score. 
Table I. Data and pedigree structure.

\begin{tabular}{lccc}
\hline Data Structure & \multicolumn{3}{c}{ Pedigree Structure } \\
\hline Number of records & 5313 & Number of base animals & 249 \\
Number of animals & 8038 & Number of animals with records & 5313 \\
Environmental effects: & & Number of sires with progeny records & 230 \\
Year of birth & $36-49$ & Number of dams with progeny records & 1510 \\
Sex of the animal & 2 & Number of grand-sires with progeny records & 269 \\
& & Number of grand-dams with progeny records & 1072 \\
\hline
\end{tabular}

- Ferocity $(\mathrm{Fe})$ - Strength; feeling of danger. The ability to attack with strength using the whole body.

- Mobility (Mo) - Movement. The animal is in continuous movement pacing from one place to another especially when provoked by a person waving a lure.

These behavioural traits mainly include their reaction to fear in different situations, e.g., when separated from their group and novelty and surprise inducing fear are presented.

The Aggressiveness and Ferocity traits were scored from 0 to 10 with 0.5 the minimum difference between the different scores while the Mobility trait was scored into four categories.

A Kolmogorov normality test [14] was carried out to check that the traits were normally distributed.

The structure of the data is shown in Table I with g-connected data [16] guaran- tied. Pedigree information has been available since the beginning of the XXth century and phenotypic data became available in 1959 (Fig. 1). Data collected up to 2001 was used; however, the animals included in the analysis were those born before 1999 .

\subsection{Genetic model}

Genetic parameters were estimated using a multivariate REML procedure [10] applied to the following mixed linear model

$$
\mathbf{y}_{\mathbf{i}}=\mathbf{X}_{\mathrm{i}} \beta_{\mathrm{i}}+\mathbf{Z}_{\mathrm{i}} \mathbf{u}_{\mathrm{i}}+\mathbf{e}_{\mathrm{i}}
$$

where:

$\mathbf{y}_{\mathrm{i}}=$ vector of observations for trait $i$

$\mathbf{X}_{\mathrm{i}}=$ the matrix that relates fixed effects to measures for trait $i$

$\beta_{i}=$ vector of unknown fixed effects for measures of trait $i$ and which included the year of birth and sex of the animal for all traits

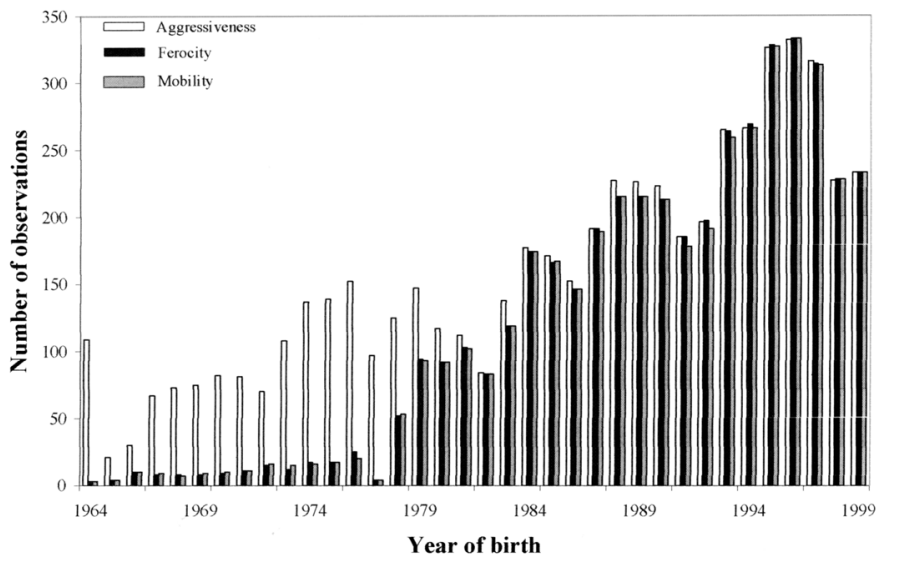

Figure 1. Evolution of recording throughout the year of birth. 
$\mathbf{Z}_{\mathrm{i}}=$ the matrix that relates animal of record to measures for trait $i$

$\mathbf{u}_{\mathrm{i}}=$ vector animal additive genetic effects for measures of trait $i$

$\mathbf{e}_{\mathrm{i}}=$ vector of residual effects for measurements of trait $i$.

It is assumed that

$$
\operatorname{var}\left[\begin{array}{c}
u_{1} \\
u_{2} \\
u_{3} \\
e_{1} \\
e_{2} \\
e_{3}
\end{array}\right]=\left[\begin{array}{cccccc}
g_{11} A & g_{12} A & g_{13} A & 0 & 0 & 0 \\
g_{21} A & g_{22} A & g_{23} A & 0 & 0 & 0 \\
g_{31} A & g_{32} A & g_{33} A & 0 & 0 & 0 \\
0 & 0 & 0 & r_{11} & r_{12} & r_{13} \\
0 & 0 & 0 & r_{21} & r_{22} & r_{23} \\
0 & 0 & 0 & r_{31} & r_{32} & r_{33}
\end{array}\right]
$$

where $g_{11}, g_{22}$ and $g_{33}$ are the additive genetic variance for traits 1,2 and 3 respectively; $g_{12}=\mathrm{g}_{13}=g_{21}=g_{23}=g_{31}=g_{32}$ are the additive genetic covariance between the traits and $r_{i j}$ are the elements of $\mathbf{R}$, variance and covariance matrix for residual effects, with $\mathbf{A}$ representing the additive relationship matrix. All runs were carried out using the ASREML program [4].

A model including the maternal effect was also considered, though eventually rejected since its likelihood was no different from the model without the maternal effect.

Genetic trends were determined averaging the predicted breeding value over the year of birth. A hypothesis test was used to test for differences in the performances between the sexes.

\section{RESULTS AND DISCUSSION}

Heritabilities, genetic and phenotypic correlation estimates, and approximate standard errors are shown in Table II. Estimates of the amount of the additive genetic component indicate that genes account for about one third of the variance in Aggressiveness, Ferocity, and Mobility. The levels of heritabilities were moderate but could be considered high if the subjective nature of these traits were taken into account, therefore, an
Table II. Heritabilities (diagonal) and genetic (above diagonal) and phenotypic (below diagonal) correlations for the three traits analysed. Standard errors are between brackets.

\begin{tabular}{|c|c|c|c|}
\hline & Ferocity & Aggressiveness & Mobility \\
\hline Ferocity & $\begin{array}{c}0.296 \\
(0.031)\end{array}$ & $\begin{array}{c}0.257 \\
(0.080)\end{array}$ & $\begin{array}{c}0.243 \\
(0.086)\end{array}$ \\
\hline Aggressiveness & $\begin{array}{c}0.181 \\
(0.019)^{*}\end{array}$ & $\begin{array}{c}0.362 \\
(0.031)\end{array}$ & $\begin{array}{c}0.142 \\
(0.087)\end{array}$ \\
\hline Mobility & $\begin{array}{c}0.224 \\
(0.018)^{*}\end{array}$ & $\begin{array}{c}0.251 \\
(0.017)\end{array}$ & $\begin{array}{c}0.286 \\
(0.033)\end{array}$ \\
\hline
\end{tabular}

* Significant at 0.05 level.

acceptable response to selection should be expected. This relatively high additive genetic effect estimates may be due to assortative mating, as also pointed out by Langlois [6] and Langlois et al. [7] in horse breeding. These authors found that the deviation of these parameters from those under panmixia can be expected as a consequence of the linkage disequilibrium, which can be generated by selection but also by assortative mating. Positive, though not significant, genetic correlation among the traits has been found which indicates a lack of non-desirable correlated response.

One further step would be to look at what extent an important amount of the genetic differences between individuals can be assigned to single genes.

Not many references involving the estimation of genetic parameters in fighting bull cattle are found in the literature. A heritability of Aggressiveness score (a mixture of Aggressiveness and Ferocity) which ranged between 0.13 and 0.47 was obtained by Montaner [9] using data from Spanish herds. Previous to that, a global score of ability to perform was obtained from a Mexican herd [5] using classical methodology and resulted in a heritability estimate of 0.19 and from a Colombian herd [2] with heritabilities ranging from 0.19 to 0.24 .

Given that we are dealing with a subjective trait, the variability of the genetic parameter estimates found in the literature is not 

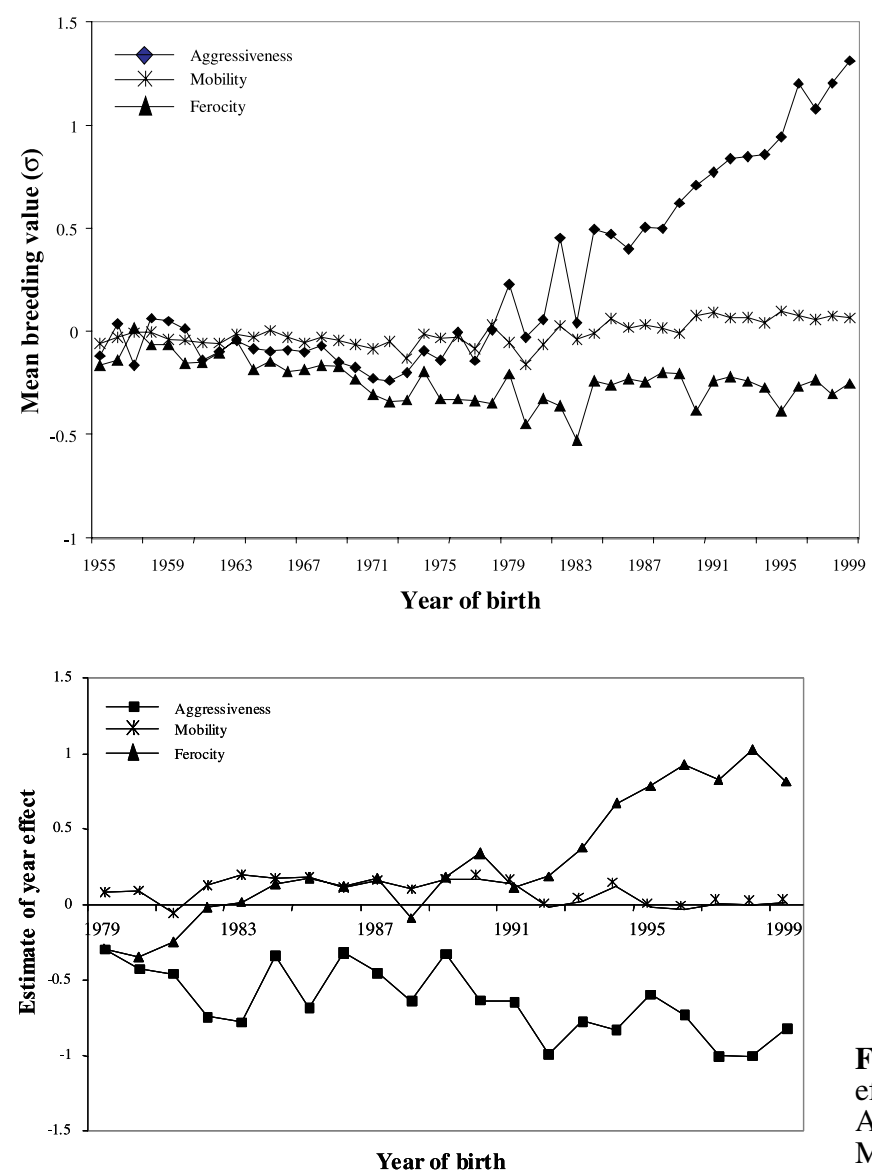

Figure 2. Genetic trends averaging genetic merits $(\sigma)$ for Aggressiveness, Ferocity and Mobility by year of birth.

Figure 3. Estimate of the year effect by year of birth for Aggressiveness, Ferocity and Mobility.

surprising. The few estimates found for cattle behaviour traits, with values ranging from 0.20 for docility [8] to 0.67 for reaction to restraint [3], together with those in the present paper seem to guaranty that traits involving Aggressiveness have a genetic base and, thus, genetic response, e.g. the reduction of the aggressiveness level, can be expected with appropriate selection. Although this evidence exists, Plusquellec and Bouissou [12] failed to find phenotypic differences in Aggressiveness between two cattle breeds (Hérens and Brune des Alpes) diversely selected for intra-specific fighting. The graphs of Genetic trends (Fig. 2) show little change occurring in the population until the beginning of performance recording in 1959. This pattern continued for the Agg trait with a slight decrease for Fe until the change in data collection criteria implemented in 1979. Figure 2 shows a dramatic increase for the first trait though little additional change in the Fe and Mo traits after the change in data collection criteria. It can thus be inferred that the selection objective in this population has been to increase Agg.

As a result of including the year of birth as a fixed effect in the model, the estimates of its levels can be drawn to show the evolution of the scores related to the year of birth (Fig. 3). These estimates primarily reflect the change in how the data collector, 
Table III. Adjusted mean estimates of Aggressiveness, Ferocity and Mobility by sex of the animal. In brackets the standard errors.

\begin{tabular}{ccccc}
\hline Sex & No. & Aggressiveness & Ferocity & Mobility \\
\hline Bull & 2026 & $6.51^{\mathrm{a}}(0.032)$ & $6.67^{\mathrm{a}}$ & $2.35^{\mathrm{a}}$ \\
& & & $(0.032)$ & $(0.015)$ \\
Cow 3287 & $6.71^{\mathrm{b}}(0.027)$ & $6.88^{\mathrm{b}}$ & $2.56^{\mathrm{b}}$ \\
& & & $(0.026)$ & $(0.012)$
\end{tabular}

Different letter by column means significant differences at $P<0.05$.

which was the same across years, scored animals over time. Scoring was quite variable until 1979 when, owing to a change in data collectors, it became more balanced. Furthermore, since that time, a trend to score higher year after year for the Fe trait and the opposite for the Agg trait has been seen.

In the same way, differences between sexes (note: the sex effect could be confused with other non-genetic effects such as age and the place where the trait is recorded, i.e., plaza vs. tienta) were estimated with better scores for females $(P<0.05)$ being demonstrated in the three traits (Tab. III).

The main conclusion of this study is the confirmation of a genetic basis for behavioural traits related to Aggressiveness and Ferocity which can then be used to carry out breeding programmes in order to get a significant genetic trend following the desired aim.

\section{ACKNOWLEDGEMENTS}

This study received the financial support of CICYT and FEDER (contract 2FD97-1191). We would like to thank J.P. Domecq and to the staff of the Fighting Bull Breeder Association (UCTL) for providing access to the data bank and the reviewers for their helpful comments on this article.

\section{REFERENCES}

[1] Cue R.I., Harris B.L., Rendel J.M., Genetic parameters for traits other than production in purebred and crossbred New Zealand dairy cattle, Livest. Prod. Sci. 45 (1996) 123-135.

[2] Durán D.V., Domínguez J.F., Heritability and repeatability of scores for fighting potential and ability in a herd of fighting cattle in Colombia, Acta Agronómica, Universidad de Colombia 45 (1995) 129-139.

[3] Fordyce G., Goddard M.E., Seifer, G.W., The measurement of temperament in cattle and the effect of experience and genotype, Proc. Aust. Soc. Anim. Prod. 14 (1982) 329-332.

[4] Gilmour A.R., Cullis B.R., Welham S.J., Thompson R., ASREML Reference Manual, Proc. 6th World Cong. Genet. Appl. Livest. Prod., Australia, 1998.

[5] González E., Durán D.V., Domínguez J.F., Heritability and repeatability of the "nota de tienta' and 'notade lidia' traits in a herd of fighting bull cattle, Arch. Zootech. 43 (1994) 225-237.

[6] Langlois B., Proposition d'extension du modèle génétique classique à des situations non panmictiques, Ann. Génét. Sél. Anim. 13 (1981) 151-164.

[7] Langlois B., Blouin C., Tavernier A., Nouveaux résultats d'estimation de l'héritabilité des gains en course des pur sang en France, Genet. Sel Evol. 28 (1996) 275-283.

[8] Le Neindre P., Trillat G., Sapa J., Menissier F., Bonnet J.N., Chupin J.M., Individual differences in docility in Limousin cattle, J. Anim. Sci. 73 (1995) 2249-2253.

[9] Montaner L.J., Heredity of the falling condition in lidia cattle, Master's Thesis, Kansas State University, EEUU, 1991.

[10] Paterson H.D., Thompson R., Recovery of interblock information when block sizes are unequal, Biometrika 58 (1971) 545-554.

[11] Plomin R., Genetics and general cognitive ability, Nature 402 (1999) 25-29.

[12] Plusquellec P., Bouissou M.-F., Behavioural characteristics of two dairy breeds of cows selected (Hérens) or not (Brune des Alpes) for fighting and dominance ability, Appl. Anim. Behav. Sci. 72 (2001) 1-21.

[13] Sandnabba N.K., Predatory aggression in male mice selectively bred for isolationinduced intermale aggression, Behav. Genet. 25 (1995) 361-366.

[14] SAS, SAS/STAT User's Guide, Vol.1, 4th ed., SAS Institute Inc. Cary, NC, 1989.

[15] Schneider-Stock R., Epplen J.T., Congenic $\mathrm{AB}$ mice, a novel means for studying the (molecular) genetic aggression, Behav. Genet. 25 (1995) 475-482.

[16] Searle S.R., Linear models for unbalanced data, John Wiley and Sons, 1987.

[17] Wieckert D.A., Social behavior in farm animals, J. Anim. Sci. 32 (1971) 151-162. 